\title{
Exploring career advancement challenges people with disabilities are facing in the South African work context
}

\begin{tabular}{|c|c|}
\hline \multicolumn{2}{|c|}{$\begin{array}{l}\text { Authors: } \\
\text { Ingrid L. Potgieter }{ }^{1} \\
\text { Melinde Coetzee }^{2} \\
\text { Themba Ximba }^{1}\end{array}$} \\
\hline \multicolumn{2}{|c|}{$\begin{array}{l}\text { Affiliations: } \\
{ }^{1} \text { Department of Human } \\
\text { Resource Management, } \\
\text { University of South Africa, } \\
\text { South Africa }\end{array}$} \\
\hline \multicolumn{2}{|c|}{$\begin{array}{l}{ }^{2} \text { Department of Industrial } \\
\text { and Organisational } \\
\text { Psychology, University of } \\
\text { South Africa, South Africa }\end{array}$} \\
\hline \multicolumn{2}{|c|}{$\begin{array}{l}\text { Corresponding author: } \\
\text { Ingrid Potgieter, } \\
\text { visseil@unisa.ac.za }\end{array}$} \\
\hline \multicolumn{2}{|c|}{$\begin{array}{l}\text { Dates: } \\
\text { Received: } 13 \text { May } 2016 \\
\text { Accepted: } 23 \text { Nov. } 2016 \\
\text { Published: } 28 \text { Feb. } 2017\end{array}$} \\
\hline \multicolumn{2}{|c|}{$\begin{array}{l}\text { How to cite this article: } \\
\text { Potgieter, I.L., Coetzee, M., \& } \\
\text { Ximba, T. (2017). Exploring } \\
\text { career advancement } \\
\text { challenges people with } \\
\text { disabilities are facing in the } \\
\text { South African work context. } \\
\text { SA Journal of Human } \\
\text { Resource Management/SA } \\
\text { Tydskrif vir } \\
\text { Menslikehulpbronbestuur, } \\
\text { 15(0), a815. https://doi.org/ } \\
\text { 10.4102/sajhrm.v15i0.815 }\end{array}$} \\
\hline \multicolumn{2}{|c|}{$\begin{array}{l}\text { Copyright: } \\
\text { (C) 2017. The Authors } \\
\text { Licensee: AOSIS. This } \\
\text { is licensed under the } \\
\text { Creative Commons } \\
\text { Attribution License. }\end{array}$} \\
\hline \multicolumn{2}{|l|}{ Read online: } \\
\hline apis: & $\begin{array}{l}\text { Scan this QR } \\
\text { code with your } \\
\text { smart phone or } \\
\text { mobile device } \\
\text { to read online. }\end{array}$ \\
\hline
\end{tabular}

Orientation: South Africa has faced a number of discriminatory practices in the past. Most of these practices are still present today. Although a considerate amount of attention has been given to discrimination based on gender, race and religion, limited emphasis has been placed on discrimination based on disability, specifically within the workplace.

Research purpose: The objective of the study was to explore the perceptions of individuals living with a disability with regards to career advancement challenges they face in the South African workplace.

Motivation for study: The research literature shows that irrespective of employment equity legislation, employees with disabilities have restricted opportunities to advance in their careers. Research is needed to assist these employees with their career development.

Research design, approach and method: A qualitative research design with an exploratory approach was followed. Probability, purposeful and snowballing sampling techniques were applied in this study on 15 employed individuals with declared disabilities. The data were collected by means of semi-structured interviews and the verbatim transcriptions were analysed by content analysis.

Main findings/results: The findings indicated that people with disabilities generally experience career advancement challenges and reach career plateau. Managers and colleagues' lack of knowledge about disability has an adverse impact on the careers of people living with a disability. The study found that human resource practices, especially promotion opportunities, discriminate against employees with disabilities. Furthermore, the study further indicated that there is prejudice against invisible disabilities, and as a result, employees are reluctant to declare their disability.

Practical implications: Human resource practitioners and managers need to recognise the influence that disabilities have on the career advancement of individuals living with a disability in order to assist such individuals in their own career development.

Contribution: The findings of this study will help companies improve their practices on the integration and inclusion of employees with disabilities and also on decision-making regarding their careers.

\section{Introduction}

South Africa has faced a number of discriminatory practices in the past. Most of these practices are still present today. Although a considerate amount of attention has been given to discrimination based on gender, race and religion, limited emphasis has been placed on discrimination based on disability, specifically within the workplace (Ximba, 2016). Some of the major key challenges that employees living with a disability face today include inequality, discrimination and transformation (Marumoagae, 2012). Employees living with disabilities generally face obstacles in exercising the most important economic, political and social rights and have experienced challenges with advancement within their careers (Ximba, 2016). Despite the effort in order to increase awareness and sensitivity with regards to disability within South Africa, employees as well as individuals applying for work mostly find themselves to be the victims of employment discrimination because of their disability (Marumoagae, 2012; Ximba, 2016).

This article aims to broaden research on employment for people with disabilities by exploring career advancement challenges people with disabilities face in the South African workplace. 
The research literature shows that irrespective of employment equity (EE) legislation employees with disabilities have restricted opportunities to advance in their careers (Cole \& Van der Walt, 2014; Commission for Employment Equity [CEE], 2012; Gowan, 2010; Hernandez et al., 2008; Lourens \& Phabo, 2015; Ofuani, 2011; Watermeyer, Swartz, Lorenzo \& Priestley, 2006). However, there seems to be a dearth of research on the perspective of employees with disabilities regarding the career challenges they face in the post-apartheid South African workplace context (Ximba, 2016). The observed restricted opportunities show a need for further empirical research on career advancement challenges faced by people with disabilities. The purpose of the present study therefore was to contribute to the research literature on career advancement challenges for people with disabilities by exploring the perspectives of employees with declared disabilities. The findings from the research may contribute to the Human Resource Management field in the establishment of transformation and EE strategies focusing on employees with disabilities. Furthermore, the study may potentially assist in improving human resource practices pertaining to the career development of people with disabilities.

\section{Literature review}

Disability is a complex concept and definitions vary from country to country (Smith, 2012; Sommo \& Chaskes, 2013). According to Sing and Govender (2007), a comprehensive definition of what constitutes disability could prevent employers from recruiting candidates with 'minimal disability' for the sake of equity targets and acknowledges competences for people with disabilities. This article adopted the definition found in the Employment Equity Act (No. 55 of 1998), which defines the disabled as 'people who have a long-term or recurring physical or mental impairment which substantially limits their prospects of entry into, or advancement in, employment'.

Recruitment, selection, training and promotion are generally Human Resource Management practices used for employee career advancement. Recruitment is a process through which organisations attract potential and suitable applicants for employment opportunities (Rahmania, Akhter, Chowdhury, Islam \& Haque, 2013; Searle, 2003). Selection is a process whereby a suitable job applicant is chosen from a pool of job applicants based on selection criteria (Abbott \& Meyer, 2014). Training intends to equip employees with relevant competencies in order to perform efficiently (Chan, 2010). Promotion is an organisational practice to acknowledge employee performance by appointing an employee to a higher position with increased pay, responsibilities, benefits and autonomy (Tuwei, Matelong, Boit \& Tallam, 2013). However, it seems from the research literature that human resource practices tend to discriminate against employees with disabilities because they generally are underrepresented in the workplace (Ximba, 2016). The research literature clearly indicates that individuals living with a disability feel excluded from the labour market because of discrimination based on their disability, which may allude to their underrepresentation in the workplace (Christianson, 2012; Ofuani, 2011).

South Africa (as a developing country) enacted legislation changes to redress imbalances that resulted from the past. Apartheid was characterised by inequalities experienced by previously disadvantaged South African citizens. Prior to 27 April 1994, people with disabilities did not have legal provisions in employment. People with disabilities were deemed incapable of participating in the open labour market (Parlalis, 2013). According to the Department of International Relations and Cooperation (2013), South Africa was re-admitted as a member of the International Labour Organisation (ILO) on 26 May 1994 and pledged to comply with ILO standards to eliminate discriminations at work which arose on the basis of race, sex, colour or disability. The South African context focuses on legislations that have an effect on socio-economic issues pertaining to people with disabilities in the South African workplaces (Ximba, 2016).

As a result, the South African democratic government enacted legislations to redress employment inequalities experienced by people from the designated groups (black people, women and people with disabilities). Legislations such as the Constitution of the Republic of South Africa, 1996, the Employment Equity Act (No. 55 of 1998) and the Promotion of Equality and Prevention of Unfair Discrimination Act (No. 4 of 2000) intended to transform organisations to be representative of all South African workforce demographics. These legislations attempt to create an inclusive and accommodative workplace environment for all. Employers are guided by Codes of Good Practice on how to successfully integrate people with disabilities and enable them to perform well in their roles. However, the legislation, aimed to protect against discrimination, still seems to fail the very people it intended to promote and protect (Ofuani, 2011; Ximba, 2016).

Ximba (2016) posits that the legislation merely created awareness of the need for equality and the right of workers to employment and to decent working conditions. The question therefore arises: is the legislation adequate to address the discrimination and inequality experienced by individuals living with a disability? Oosthuizen and Naidoo (2010) found that organisations only comply with EE legislative requirements in an 'EE numbers chasing game', where employers are only concerned with increasing EE and Affirmative Action (AA) figures rather than improving their EE status quo through value-adding investments. Oosthuizen and Naidoo (2010) further argue that EE and AA progress should be measured on the criteria of numbers as well as their organisational climate.

Workplaces within the 21st century necessitate a paradigm shift from merely meeting EE prerequisites to creating an amicable workplace that is inclusive of employees with disabilities (Daya, 2014; Hasse, 2011). Several factors (such as age, race, religion, gender, occupational levels and disabilities) 
influence the career growth of employees, which cause challenges such as underemployment, low wages, bias and limited advancement opportunities (Beatty, 2012; Gowan, 2010; Ofuani, 2011). According to Lengnick-Hall and Gaunt (2007), employees with disabilities are assumed to be incompetent, not productive and create undue hardship for the business; hence, they face limited career advancement opportunities.

Despite the legislations implemented to redress discrimination against employees with disabilities, Hernandez et al. (2008) found that employees with declared disabilities mainly occupy entry-level and semi-skilled positions. Many adults with disabilities are either unemployed or occupy positions characterised by low wages with little or no chance of advancement (Lindstrom, Doren \& Miesch, 2011). Individuals with disabilities are therefore faced with limited career advancement opportunities, even if they meet the stipulated minimum requirements (Gowan, 2010; Ofuani, 2011; Watermeyer et al., 2006).

The CEE (2012) report indicated that white men and individuals without disabilities are more likely to be recruited and promoted within most organisations. Hernandez et al. (2008) and Beatty (2012) suggested that the most prevalent factor influencing these barriers that individuals with disabilities face is because of management perceptions with regards to the ability of these employees.

Christianson (2012) also noted that people with disabilities may have either or both the qualifications and the capacity to be employed, but that this decision depends on employers' willingness to provide reasonable accommodation for a disabled candidate.

Guimaraes, Martins and Barkokebas Junior (2012) found that a lack of professional training, architectonic barriers and discrimination based on functional potential hinder the inclusion of people with disabilities in the labour market. According to Gida and Ortlepp (2007), ignorance, fear and stereotypes are the main reasons for a low representation of people with disabilities in the workplace. Gida and Ortlepp (2007) noted that organisations do not have a strategy or policy document for the employment of people with disabilities. The South African Human Rights Commission (2012) advocated that scarce employment opportunities and inadequate marketable skills exacerbate the unemployment of candidates with disabilities. It is thus evident that equal opportunities between people with disabilities and people without disabilities have not been attained (Ofuani, 2011). People with disabilities do not have equal employment opportunities as do people without disabilities and this adversely impacts on them ( $\mathrm{Li} \&$ Goldschmidt, 2009).

The employment of people with disabilities benefits the organisations because they earn Black Economic Empowerment (BEE) points and achieve EE targets, which makes an organisation appear civically oriented to the community in which it operates (Sing \& Govender, 2007; Watermeyer et al., 2006). Transformed organisations therefore stand good chances to get lucrative contracts with the government or private companies because of their BEE and EE statuses. Several other benefits have been reported to having employees living with a disability. These include a diverse workforce, low absenteeism rates and long tenure (Parlalis, 2013). In addition, Hernandez et al. (2008) found that people living with disabilities are committed, reliable, loyal and hardworking. The ILO (2011) states that people with disabilities bring benefits such as good, dependable employees, untapped skills, creativity and high work ethic. In addition, they enhance the company's public image. According to the ILO (2011), a number of employers do not know the benefits of recruiting people with disabilities as they are not sensitised to disability matters. The workplaces are thus not inclusive to all employees.

Perceptions of employees with disabilities are the greatest barrier that hinders transformation to be representative of employees with disabilities. Management can play an active role in transforming organisations by changing perceptions of candidates with disabilities. To create inclusive workplaces, employers should be sensitised about the legislative prerequisites to integrate job applicants with disabilities and eradicate preconceptions about the capabilities and competences of the disabled community (ILO, 2011; Parlalis, 2013). However, the literature does not provide the perspective of employees with disabilities regarding the career advancement challenges they face especially in the South African work context.

\section{Research purpose}

This study explored the perceptions of individuals with disabilities regarding the career advancement challenges they face. The findings of the study may be used to formulate suggestions for future research and the development of transformation agenda strategies relating to the career development of people with declared disabilities.

\section{What will follow}

The following section of this article elaborates on the research design. The section includes the research approach, strategy and method, followed by the discussion of the findings. A brief summary of the main conclusions, implications for practice and recommendations for potential future research concludes this article.

\section{Research design \\ Research approach}

This study was done as an exploratory research effort to increase insight into the perceived factors that influence career advancement of individuals living with a disability within South Africa. A qualitative explorative approach was used in this research. The researcher thus aimed to describe the lived experiences of participants as accurately as 
possible, without being influenced by any pregiven framework (Thomas, 2004). This was done by collecting more situational information and determining the meanings and purposes that individuals ascribe to their actions (Guba \& Lincoln, 1994).

\section{Research strategy}

In this transcendental or descriptive phenomenological study, employees with declared disabilities were interviewed who are employed by two group companies in different sectors within the Gauteng province. According to Leedy and Ormrod (2010), a phenomenological study is a study that attempts to understand an individual's perception, perspective and understanding of a particular situation.

\section{Research method}

\section{Research setting}

The research setting refers to the place where the data will be collected. In this study, the data were collected from companies in the retail and financial service sector in Gauteng province. The interviews were conducted at the participants' place of work in a setting provided by the participants' employers. The research setting and physical environment are vital as these aspects can influence the outcome of the research (King \& Horrocks, 2010; Terre Blanche, Durrheim \& Painter, 2006). Therefore, the researcher made sure the interview setting was comfortable, allowed for privacy and that it was a quiet surrounding during the interviews.

\section{Entree and establishing researcher roles}

After permission was granted to conduct the study, the researcher explained and clarified the research objectives and procedures with the main decision makers within the selected organisations. The institutions appointed a gatekeeper who assisted the researcher with logistical aspects of the research. The gatekeeper also assisted in communicating the research opportunity to employees, identified possible participants and scheduled all the interviews (De Vos, Strydom, Fouche \& Delport, 2011; Maxwell, 2005). In order to ensure that quality data were collected (Boyce \& Neale, 2006), the researcher was trained suitably in interviewing techniques (Neuman, 2003). Several authors emphasised the importance of reflexivity in quality research (Boyce \& Neale, 2006; Terre Blanche et al., 2006). The researcher thus made time after each interview in order to reflect on the interview and recorded these reflections as part of the field notes.

\section{Participants and sampling}

A purposive, voluntary non-probability sample of 15 employees with declared disabilities was included in this study. These employees were selected from two separate group companies (within different sectors) within the Gauteng region. Only participants who have declared their disabilities with their employers were included in the sample. Employees who complied with the inclusion criteria and were willing to participate were included in the sample.
The number of participants in the sample was determined by data saturation (Burns \& Grove, 1997).

The sample $(n=15)$ comprised $5(34 \%)$ participants from African origin, $2(13 \%)$ participants from coloured origin, 1 (7\%) participant from Indian origin and 7 (47\%) white participants. The participants included 10 (67\%) women and $5(33 \%)$ men. There were no coloured and Indian male participants. Most of the participants were employed in semi-skilled positions. None of the participants was employed in unskilled or top management-level positions. The participants were predominantly between the ages of 41 and 50 years (maintenance career phase, middle adulthood). Eleven participants have been with their employers for between 6 and 30 years and 4 participants for between 1 and 5 years. The range of the declared disabilities included:

- hearing impaired

- amputation

- bipolar or other psychological disorders

- physical disability

- epileptic and brain tumour

- learning disability

- partial sighted.

\section{Data collection methods}

In this research, data were collected by means of semistructured individual interviews. After giving informed consent, the participants were asked eight standard successive questions. Questions 1-3 dealt with obtaining the biographical profile of the participants. The first question, which served to identify whether the employee do indeed have a disability, was 'What is the nature of your disability'. The second question ('What is your race, age, gender and occupational level') was asked to assist the researcher to determine the profile of the sample. The third question, 'How long have you been employed in this organisation' helped to identify the likelihood for an employee to be provided with career advancement opportunities.

Questions 4-8 dealt with obtaining the core career advancement issues faced by the participants. The fourth question, 'Since your employment in this organisation, what are the career advancement challenges you have experienced' helped to identify the career advancement challenges the participants face. The fifth question, 'How did the career advancement challenges adversely influence your career' was asked to identify the effect of the career challenges. The sixth question, 'What impact do you race, age, gender and occupational levels have on your career advancement opportunities' was asked to help identify if participants from different race, age, gender and occupational levels differ significantly regarding their perceptions of career advancement challenges. Question 7, 'How does your disability impact your career advancement opportunities in the organisation' was asked to help identify if participants' disabilities influence their career advancement opportunities, and finally, question 8, 'What suggestions could you propose to management to overcome the career advancement 
challenges you are currently facing due to your specific disability' was asked to assist with interventions and suggestions to management in order to redress identified challenges.

\section{Recording of data}

Interviews were recorded and detailed field notes were made (also known as observation notes). According to Hesse-Biber and Leavy (2004), field notes are an explanation of the researcher's experience (including his or her sight, hearing and thought during the interview process). The field notes can be classified as either methodology notes, personal notes or theoretical notes. All the field notes as well as verbatim transcripts were prepared for data analysis. All field notes, transcriptions and interviews were labelled by means of a coding system (only known by the researcher and transcriber) in order to maintain confidentiality. The anonymity of all data (audio files' content and field and transcription notes) was upheld, and data were stored in a secure place in order to ensure further confidentiality.

\section{Data analyses}

The obtained data were analysed using content analysis. According to Hesse-Biber and Leavy (2004), content analysis is a systematic technique that gathers and combines a large amount of text into identifiable and specific content categories, which can be analysed. Content analysis focuses on content and contextual meaning of the text. The researcher is thus able to draw replicable and valid inferences from the content (Hsieh \& Shannon, 2005). In order to get the bigger picture of the content, the researcher thoroughly read the interviews a number of times. The researcher then categorised the actual text (responses from the participants) into meaningful pieces of sentences and paragraphs. These pieces were then categorised and sorted into major themes.

\section{Strategies to ensure quality data}

Principles with respect to quality data were maintained in this research. These principles include accuracy, context and density of descriptions, usefulness and reflexivity (Richards, 2009). The following methods were employed in this study: (1) clear and careful descriptions of each stage of the research was outlined, (2) comprehensive field notes were taken after each interview, (3) an independent professional transcriber were assigned, (4) critical open discussions between the researcher and transcriber on the process and the results of the data analysis were held and (5) clarification and confirmation of themes with some participants were done. To establish trustworthiness of the qualitative research, the terms credibility, authenticity, transferability, dependability and confirmability are used as equivalents for internal validity, external validity, reliability and objectivity (Creswell, 2007). In order to ensure trustworthiness in this research, the researcher consulted theoretical literature applicable to the research topic and adapted a triangulation strategy in order to compare varied sources of theoretical data or common themes. The researcher furthermore took preliminary analysis of descriptions or themes to participants for their confirmation of the accuracy and validity of the analysis.

\section{Ethical considerations}

Ethical procedures were ensured in this study. Each participant was provided with a participation information sheet, clearly indicating the purpose of the study as well as the procedure to follow should the participant experience stress or emotions because of the participation in the study. In addition, the researcher received an informed consent from each participant. The researcher maintained confidentiality by ensuring that the data were available only to the researcher. Ethical clearance was obtained for the project by the institutions' research and ethics' committee as well as the organisations were the interviews were conducted.

\section{Reporting}

In the subsequent findings section, the major influential perceptions and subsequent sub-perceptions are discussed.

\section{Findings}

Data analysis of the interview data on research questions 4-8 yielded various themes relating to the career advancement issues faced by the respondents. Table 1 summarises the three main themes and various subthemes that were identified using Tesch's (1990) method of content analysis: (1) career advancement challenges, (2) impact of demographics on career advancement and (3) suggestions to management on assisting in overcoming the career advancement challenges in the company.

\section{Theme 1: Career advancement challenges}

Table 1 shows that 7 subthemes emerged from question 4 while six subthemes emerged from question 5 .

Question 4: Since your appointment in this organisation, what are the career advancement challenges you have experienced? The subthemes related to no career advancement opportunities, slow or no promotion opportunities, the work environment not being conducive for people living with a disability, no prospect of employment opportunities or not being selected, lack of disability awareness from the organisation or lack of understanding of the disability, EE requirements and educational level.

Question 5: How did the career advancement challenges adversely influence your career? The subthemes related to hindered disability declaration, no salary increase, bonuses and promotion, including demotions, job specifications or company policy not conducive for people living with a disability, lack of influence, reliance on colleague support to perform core duties and negativity and aspiration.

According to the findings, the most common career advancement challenges individuals living with a disability 
TABLE 1: Summary of the core themes pertaining to career advancement issues faced by people with disabilities.

\section{Theme} Sub-theme Example of quotes

\section{Career advancement challenges}

Question 4: Since your employment in this organisation, what are the career a challenges you have experienced?

No career advancement challenges

Slow or no promotion opportunities

Environment not conducive for people living with a disability

No employment opportunities or not being selected

Lack of disability awarenes from the organisation or lack of understanding

Employment equity requirements

Educational leve

Question 5: How did the Hindered disability career advancement challenges adversely influence your career declaration

No increase, bonuses and promotion. Was demoted Job specifications or company policy to be conducive for people livin with a disability

No influence

Rely on colleagues assistance to perform core responsibilities

Negativity and no aspiration

Participant 12: 'I did not experience any challenges. They are very fair. It is about your capability and your performance. So there were no career advancements due to my disability and I also was not favoured because of my visibility, disability. It is fair'.

Participant 8: 'To be quite honest, I had my whole career smooth. It was only when I declared my disability that my challenges started. So my whole (company name) career was smooth and then in two thousand and eleven I got the opportunity to go through to a branch... Now the job challenged my abilities because I told you I have got a short, a weak short-term memory and there you need to juggle a whole lot of tasks. I am better at jobs where I need to concentrate on one thing .... and so the manager that time said if you declare you disability we can help you and I have not seen that help'.

Participant 5: 'If you work in an organisation like this it is set up not for a person with disability, that I must say, and it is a totally not set up for a person with a disability and if you are going to be here you need to have the nerves to be in the organisation and have the ability to cope with whatever that is happening'

Participant 6: 'I have applied to close to about two hundred and thirty-four jobs and out of those ones I have been to about five interviews since that time and I have given up looking for a job... I lose concentration. I make a lot of mistakes basically. So I think that is the reason why I cannot get a job elsewhere because I am not competent enough because I am always making mistakes and they have not fired me yet, which is good...

Participant 11: 'The challenges are from sheer corporate ladder mobility prospective I have never had those types of challenges. However, when you say in terms of growth and training and enhancements of skills what it means is that when I attend training and for instance they show videos and there are no subtitles I battle. I have raised it a number of instances already with our training centre saying, please could you put subtitles when you show videos? Corporate videos, whatever-whatever, all these training materials that is let's say video or...based it is very difficult for me. If it is a presenter or if I go to a conference you will always find me in the front rows. I am one of those who does not mind going to the front row because I do a lot of lip reading, not that I have learned but...so if it's a one-on-one...if it is presented easier but if it's videos it's a nightmare for me. I just switch off because it requires such a degree of concentration that I battle. I would rather drive to (other office) to have a meeting face-to-face and come back than do a telecom. People say why do not you do a telecom? Because I need to see the person. It is easier for me. So those are the type of challenges that I face and especially with the evolution of audio and video conferencing is a challenge for $\mathrm{me}^{\prime}$.

Participant 7: 'The only disability would be my race. I am a pale male as people would call it. I am a white Caucasian and because of affirmative action and we need to meet certain targets set by the Department of Trade and Industry it's been quite clearly made known that we are looking for black people to fill that role and so that is not really disability, that is just historical situation to the country. That is the only area where I have seen limitations in progress in some areas but that is part and parcel of where we are. I am not bemoaning the fact. I embrace the whole thing that needs to take place and I look for other avenues to use my talents. I have operated as everybody else realising I need to work maybe a little bit harder in some areas because of the disability challenges'.

Participant 9: 'My career advancement challenges that I have experienced is that I am still in the same position as I came in. So there are not a lot of opportunities for disabled people within the organisation especially when you only have a matric'.

Participant 3: 'I would have felt more comfortable to declare my disability. I was just scared and not trusting of people and I did not want to be discriminated against. I was scared of that. Just did not have the confidence'.

Participant 4: '...I was not getting the increases, bonuses and promotions that my colleagues were getting I think what I am experiencing is that I am now at a lower grade than I would have been otherwise'.

Participant 5: 'When, for example I want to apply for a job. Because I had missed a day because I could not come to work and as a result of the system that is working where I cannot ask for a leave in a short space of time as a result I find that, no, I cannot come to work. Then you leave, you do not come to work, that is going to count when you are applying for a job because now you have not come to work and you were supposed to be at work and it is called compliance and if you are because now you have not come to work and you were supposed to be at work and it is called compliance and if you are small things but they will count when you are applying for a job. So it is those things that we have to go through each and every day and...but anyway opportunities they say that they are there but when you look at what is given on that as a every day and...but anyway opportunities they say that they are there but when you look at what is given on that as a
specification for that job you find that the bar is too high and you might not get there. So those are things but anyway'.

Participant 6: 'I do not feel I have to go to school to get something so that I can be something because I went to school, got an NOF, and I am not working in that department so it is pointless...So I have decided I am fine with my job... And even if I get concentration I am not trying to be a manager because I cannot even manage the chickens and the pigs in my yard or my son. So how am I going to manage people? I can handle my stress. I am not trying to exert myself any further than I my son. So how am I going to manage people? I can handle my stress. I am not trying to exert myself any furt
have. I feel I have accomplished everything that I need to accomplish. I am just going to sit back and relax'.

Participant 11: 'I hate my hearing aid with a passion and I think what made me eventually accept them is the day I realised that our chairman at that time was wearing hearing aids. That was for me a big ha-ha moment which helped me accept them but my mind-set has never been I am disabled or I have a partial disability... if I chair the meeting and we need to have minutes I will ask someone else to take the minutes for me'.

Participant 13: 'It has influenced...like I said I just came to a point whereby I was thinking I am working to survive. I do not have any vision anymore. I do not have drive anymore. I do not have something that I can say whereto from now? No creative ideas anymore. You just do what you do. You stay, you learn and you do what you do and you go on and it is really saddening for a person like me whereby I know there are opportunities out there but then it is scary as well. You become afraid and you become an introvert because you do not know what to expect from whoever but you know why you are there and that is how situations just present themselves... Demotivated, no self-esteem or low self-esteem....a person can become very depressed because with becoming depressed there were times that I actually got sick of just depression because I don't have a way out or anything'.

\section{Impact of demographics on career advancement opportunities}

Question 6: What impact No impact do your race, age, gender and occupational levels have on your career advancement Age opportunities?
Participant 4: 'None at all. No, I have experienced no racial discrimination, no age discrimination, no gender discrimination occupational levels. I have advanced as well as I could. So I have had the normal training opportunities. No, I cannot say there has been any discrimination on any of those grounds'.

Participant 2: 'All I think about this is when it comes to BEE score... because I am a woman and I am black and I have a disability I am considered first. So that is how the BEE score works. So most of the times they will consider us first and then if there is an opportunity we are considered first. And I am still young. When you are young, you are around twenty-five and not above thirty-five, there are more opportunities for you to work or to get promoted. So I think considering that, that is what (company name) looks at it. Even when I am doing the interviews, when I am doing the screening and everything for the learnerships or for permanent employment for people with disabilities, we consider that. If you are black and you are between the ages of eighteen to thirty-five and you a female even your pay and mine are not the same as mine because I am a female and your pay and the pay for a white normal guy is not the same because of that

Gender

Participant 8: 'Gender, once again if you look at white male it is not a preference in the work space nowadays'. Participant 13: 'As a female it is difficult with a disability, a female with a disability. It is a little difficult because to some extent males have a thing where they would accept and embrace each other with certain defects but if a woman come along and there is a defect and they class you or they place you in a box of some sort you are female'. Participant 8: 'Race, let's start with race. I hate to play the race card but, yes, especially white males do not get promotions anymore'. 
TABLE 1 (Continues...): Summary of the core themes pertaining to career advancement issues faced by people with disabilities.

\begin{tabular}{l} 
Theme \\
\hline Question 7: How does \\
your disability impact \\
your career \\
advancement \\
opportunities in the \\
organisation?
\end{tabular}

Sub-theme

No impact

Preferred for employment

organisation?

\section{Example of quotes}

Participant 3: 'Right now, at this point where I am in my career, I cannot say it impacts me greatly. It is challenging, yes. I am not sure how to answer that one'.

Participant 2: 'No, I think looking at (company name), let's say with my post now, there are a lot of people wanted this position but because they specifically wanted someone with disability...with a certain department there need to be certain people with disabilities. So sometimes they will try it by all means to get someone with a disability for that post so that it balances out but even though... remember, when you are applying for the positions, as I said before, if you are disabled your CV is considered first unlike normal people. They will consider yours first and see if you meet the criteria of what they are $\mathrm{CV}$ is consider
looking for'.

Limiting job scope and opportunities

Participant 9: '...if I say I want to apply at the call centre because with the matric it is very normal I can get a job in the call centre. I will have a problem now because I am hard on hearing and my hearing aid is not suitable for the phones. So it is going to be a challenge for me to work there because of my disability'.

Stigma and limited knowledge influence

Participant 4: 'Now this is the point at which one would talk about prejudice maybe? Prejudice against mental illness. ...it (prejudice) makes managers nervous. It is maybe harder for a manager to accept than a physical disability which is physical, it is tangible, it is measurable, it does not affect the personality of the person. Bipolar is not a personality disorder, it is a mood disorder, so it is not in the same category as schizophrenia for instance or psychosis, it is not what you might call madness, but employers do not always understand that difference and mental illness is bracketed with all kinds of other mental illness which of course cause a lot of stigma. Definitely stigma'.

Lack of reasonable Participant 5: 'I do not know how to put this one. If you have a disability... there are certain signs that you will see that they accommodation are working for you and they are not. ...for example, a director may say that I want a person with disability in that department but then in terms of the conditions that are set up for example in that area you look at them and you say should I apply for that job? No way that that department is going to have A, B, C, D which might be for example the hours that are not going to be conducive for me to be able to cope. For example, there is a department where they have a rotation of a day and night and you might be ending up with a day shift and then with a night shift... so even if that was an opportunity for me but then it takes out anything that I would have liked to do with that department'.

\section{Suggestions to management}

Question 8: What Provide disability suggestion could you sensitisation propose to management for overcoming the career advancement challenges you are of your disability?
Limited support and training opportunities

Participant 8: '...my route is not the same as everybody else and I need a bit more help from management. In other words, them offering me a training programme or so but I cannot do it on my own. Since I am here it is almost like I am on my own'

Participant 9: 'The suggestion that I could now propose to the management is take time to understand our disabilities. You should not just employ us because they want to say that (company name) use disabled people, we are treating people equally, but try to understand the background, the nature of our disabilities, try to make the environment more suitable for us..."

Participant 5: 'My suggestion would be first a thorough research as to how to accommodate a person with disability in work environments to be done. It has not been done as yet, that is my feeling at the moment. It has not been done or maybe, if it was done, it was not done like for example talking to a person with disability.

was done, it was not done like for example talking to a person with disability. And policies, that is what I always say policies are designed by a person and that person must design the policy in order to accommodate the employee and that person, if he is clued or has the idea as to what it is that is happening, then he will be
able to understand what it means and that is why I am saying research first and then everything will come together and able to understand what it means and that is why I am saying research first and
then people with disability will be able to go to work and have no problems'.

Participant 12: '...we are also proud people and is to be employed because of my skills and what I can deliver not because

Provide permanent employment opportunities and increase responsibilities the understanding not to treat me awkwardly. Treat me like the other people but also to be sensitive'.

Provide development opportunities

Participant 8: 'The suggestion is not to look in an interview who is the strongest person like in people in my case now. Offer that training opportunity and offer that coaching on the side-line so that if something opens up that you are ready to go in there because I do not believe I am supposed to always sit at a call centre level agent one. It is not always about grades, it is not always about salary but, yes, you want that opportunity'.

Connect with employees Participant 13: '...from a HR point of view. When people are employed, and it is people with disabilities, try to find out what is happening in their lives. Do they have husband and wives, children, partners? Their social aspects. You do not have to know in detail what is happening'.

Source: Ximba, T. (2016). Career advancement challenges facing people with disability in South Africa. Unpublished Master's Dissertation. Pretoria: University of South Africa

face are because of a lack of awareness or understanding from the company's side and the environment not being conducive for people living with disabilities. Furthermore, the participants reported that they experience slow or no promotion opportunities and are less likely to be selected for a position because of their disability. However, some participants reported that they do not experience any career advancement challenges within their companies. It seems as if the participants who received support from their management and colleagues did not experience career advancement challenges. Participants $(1,2,6,7,10$ and 12) found their work environment to be inclusive, accommodative and supportive. In these instances, employers focused on participants' capabilities and performance rather than disabilities.

Some of the challenges that were mentioned include nonconducive work environment, trust issues and the reaction of colleagues after declaration. Participant 8 indicated that his career advancement challenges started when he declared his disability and management could not provide reasonable accommodation. After declaring his disability, participant 8 was reassigned and demoted to a lower role. This new role had limited career growth opportunities because of less value-adding responsibilities. Some participants reported that absence from work because of incapacity leave or hospitalisation influenced participant's pay increase, bonuses, assignment to value-adding responsibilities and promotions.

According to participants 5 and 14 , the call centre environment is not accommodating to persons with disabilities, especially for employees with hearing impairment. It is evident from the findings that employees with partial hearing impairment have challenges with access to information. Participant 7, 9, 11 and 14 argued that they had to make extra effort to understand the information being communicated either in meetings or telephonically and it was often necessary to ask for clarity. Participant 7 asserted that he has not experienced challenges, in contrary; he argued that he needs to work a little bit harder (as compared to individuals without a disability) because of the disability challenges.

According to participants 9 and 13, people lack understanding of disability. Participant 8 stressed that people are 
unsympathetic because they lack awareness and education about people with disabilities. People are not knowledgeable about disabilities, while disability declaration helped participants to get support from their managers. Five participants $(1,2,7,10$ and 12) did not experience career advancement challenges. Participant 7 asserted that 'I have been able to grow in this organisation, I have been given opportunities for growth. The organisation has treated me well and I have been surprised at some of the opportunities that have come my way'.

Participant 5 indicated that the employer did not provide parking for wheelchair users. Therefore, he cannot drive to work by himself. As a result, he is not able to work late shifts. Participant 5 also stated that absence from work was not approved because it was submitted in short notice. Such an absence record adversely affect employee records when applying for external job opportunities. Leave in short notice was inevitable at times because of the nature of the disability.

There seemed to be different influences, especially emotions, caused by the career advancement challenges the participants faced. It could be concluded that some participants were not completely aware of the influences; hence, the researcher elicited the influences during the interviews. Three female participants indicated that they were tolerant of the career challenges because they have families to support otherwise they would have left.

\section{Theme 2: Impact of demographics on career advancement opportunities}

Table 1 shows that four subthemes emerged from question 6 while six subthemes emerged from question 7.

Question 6: What impact do your race, age, gender and occupational levels have on your career advancement opportunities? The subthemes that emerged from question 6 included no impact, age, gender and race.

Question 7: How does your disability impact your career advancement opportunities in the organisation? The subthemes that emerged included no impact, preferred for employment, limiting job scope and opportunities, stigma and limited knowledge influences on personal relationships, lack of reasonable accommodation and limited support and training opportunities.

It was evident that the participants had different perspectives on career advancement challenges. The inception of BroadBased Black Economic Empowerment (BBBEE) brought changes in employment. Black participants indicated that BEE accorded them employment opportunities while white participants had limited opportunities. It was found that call centre work was not preferred for persons with various disabilities but was preferred by the younger generation. The findings indicated that women with disabilities work harder than their male counterparts. Three female participants indicated that they were tolerant of the career challenges because they have families to support otherwise they would have left.

The most prevalent impact the disability has on career advancement according to the participants was that they are sometimes preferred for a position (the position is thus reserved for an individual with a disability), but because of the disability, they are often provided with limited opportunities. The participants perceived that other colleagues hold a stigma against them and it negatively influences their relationship. They experience a lack of reasonable accommodation and feel that they are provided with limited support and training opportunities.

\section{Theme 3: Suggestions to management}

Table 1 shows that five subthemes emerged from question 8 .

Question 8: What suggestions could you propose to the management to overcome the career advancement challenges you are currently facing because of your specific disability?

The participants provided the following suggestions to management in order to redress career advancement challenges employees with disabilities face:

- provide disability sensitisation

- provide reasonable accommodation

- provide permanent employment opportunities and increase responsibilities

- connect with employees.

\section{Discussion}

This study explored the perceptions of individuals with disabilities regarding the career advancement challenges they face in the South African workplace context. Overall, the research participants were representative of all races and gender. Most of the participants occupied semi-skilled positions. None of the participants occupied unskilled or top management-level positions. Hernandez et al. (2008) and Management Today (2011) asserted that the employees with disabilities predominantly occupy entry-level and semiskilled positions. The CEE $(2012,2013,2014)$ found that white people dominate the representation of people with disabilities over black people. Statistics South Africa (2014) asserted that there are more female participants with disabilities than male participants. Hashim and Wok (2014), Hernandez et al. (2008) as well as Buciuniene and Kazlauskaite (2010) asserted that people with disabilities have a long tenure; they tend to be committed, reliable, loyal and hardworking employees.

The study found that not all people with disabilities face career advancement challenges. Five (33\%) participants indicated that they have not faced career advancement challenges in their workplaces. The perspectives of the participants regarding the challenges they faced were similar to those indicated by the research literature. The literature indicated that disability challenges hinder career 
advancements in the workplace (Hernandez et al., 2008). The findings of the present study corroborate research indicating that employers lack knowledge about disabilities and the legislative requirements (Wehman, 2011). Beatty (2012) also found that employees with disabilities experience career plateaus where they remain in the same position for a long time and that advancement to a higher level is unlikely. Zondi (2009) mentioned that people perceive that people with disabilities are not able to do well in senior positions. Van Niekerk and Van der Merwe (2013) also stress that employment, advancement and training opportunities for people with disabilities are linked to their educational levels. In agreement with the findings of the study, Crowther (1999) argues that barriers encountered by disabled people vary from social barriers (perceptions and behaviours), material barriers (inaccessible structures and information) to organisational barriers (legislation, organisational policies and procedures, economic factors and practices).

The study founded that human resource practices, especially promotion do not favour the participants because of their perceived disabilities. The participants indicated that promotion opportunities are prolonged or not afforded because of their disability. One participant even indicated that he was demoted after declaration of disability while one argued that it took her longer to be promoted because the environment was not conducive for declaration. Several authors also found that promotion is one of the most evident advancement challenges faced by individuals living with a disability (Hussein, Manthorpe \& Ismail, 2014; LaPierre \& Zimmerman, 2012; Vickers, 2009).

Similar to this study's findings, Jakovljevic and Buckley (2011) mentioned that employees fear to disclose their disabilities to employers because of perceived prejudice towards disability. Hussein et al. (2014) asserted that employees, except for employees in higher level positions and with decision-making powers, fear losing their jobs if they disclose their invisible disabilities to employers. The experiences of limited job opportunities, lack of bonuses, promotion and salary increases or permanent employment may be attributed to what Hernandez et al. (2008) view as being managers' perceptions that recruiting and appointing persons with disabilities would result in an increase in supervisory time, low productivity and frequent absence. However, in this regard, Article 38 of the Law on Protection of Disabled Persons (1990) prohibited discrimination against persons with disabilities on different grounds including pay increase, promotions and bonus. Jones (2008) asserted that an employer may equate an individual's productivity to those without disability by providing reasonable accommodation.

In line with the present study's findings, Belzil and Bognanno (2010) also mentioned that education, age and tenure are variables that influence decisions regarding promotion, scope of the position and opportunities. Similar to the participants' perceptions, Hussein et al. (2014) mentioned that employees fear losing their jobs if they declare disabilities. The study found that there is prejudice against invisible disabilities and people are unsympathetic. The participants indicated that they do not want to use their disabilities as excuses for incapacity or being sorry for, but want to be recognised for the contribution that they can make. The study findings corroborate research showing that stereotypes and stigmas against employees with disabilities are the reason for their high unemployment rates (Vickers, 2009). According to Watermeyer et al. (2006), the provision of skills advancement opportunities to all employees will help to achieve EE in the labour market. They further argue that appointments should be based on competences (skills and abilities) rather than meeting EE targets and goals. The World Health Organisation (2011) claimed that most jobs can be performed by persons with disabilities if all reasonable accommodation needs are provided.

The findings indicated that people from different race, age, gender and occupational levels differ in their perceptions regarding career advancement challenges to some extent. Female participants perceived themselves to have higher career advancement challenges than their male counterparts. In agreement with the experiences of the female participants, LaPierre and Zimmerman (2012) indicated that female participants do not progress as much as their male counterparts. White participants, especially male participants, experienced higher levels of discrimination because of postapartheid AA and EE legislation. This finding is contrary to the findings of Watermeyer et al. (2006), which suggest that black people with disabilities tend to experience inferior conditions compared to their white counterparts.

The participants provided suggestions to address the identified career barriers people with disabilities face. The suggestions were directed to management or people with influence in decision making. The most prevalent suggestions were to provide disability sensitisation and reasonable accommodations. The study findings also confirm in line with Hernandez et al.'s (2008) view that management perceptions are a barrier to initiatives to employ people with disabilities and that increased attention should be given to the provision of reasonable accommodation to employees with disabilities. Sing and Govender (2007) and Watermeyer et al. (2006) stress that employment of people with disabilities benefits the organisations because they earn BEE points and achieve EE targets, which makes an organisation appear civically minded to the community in which it operates. The participants suggested that people should undergo a disability sensitisation to learn about disability so that an inclusive, diverse and accommodative environment can be created.

\section{Limitations and future research directions}

Although this study provides comprehensive and valuable contributions in order to help identify the perceptions that employees living with a disability may have with regards to career advancement, some important limitations are worth mentioning. One such limitation is that the employees in this sample were selected from two different sectors within the Gauteng province and that the sample was relatively small. 
Thus, no generalisations can be made as the perceptions recognised and explored in this study could possibly be only representative of the particular organisations and their cultures. However, the participants' responses may still be typical of what employees in South African workplaces experience, thereby allowing for the transferability of the findings (Appleton, 1995; Terre Blanche et al., 2006). Future studies incorporating more participants from different sectors, regions and cultural or language groups might reveal additional perceptions on career advancement challenges.

\section{Conclusion}

Individuals with disabilities could contribute to developing the South African labour market. Efforts to enhance and utilise their skills should be made without being discriminated against on the grounds of their perceived disability. Employers or management need to be sensitised on disability. Disability sensitisation will equip organisations to create an inclusive and amicable workplace where employees with disabilities will be accommodated and their talent or contributions valued.

Employers should employ candidates with disabilities in meaningful roles for their skills. Employment should precede the EE and BBBEE targets. The targets may be irrelevant or change in due course while skills are critical for the businesses to sustain. This will avoid rotation of candidates with disabilities in learnerships and lower level positions without career growth.

\section{Acknowledgements Competing interests}

The authors declare that they have no financial or personal relationships that may have inappropriately influenced them in writing this article.

\section{Authors' contributions}

I.L.P was the project leader. T.X collected the data and assisted with the literature review. I.L.P and M.C conducted the data analysis and wrote up the research article.

\section{References}

Abbott, P., \& Meyer, M. (2014, July). National HR Standards Phase III: HS standards update. HR Future, 34-35.

Appleton, J.V. (1995). Analysing qualitative interview data: Addressing issues of validity and reliability. Journal of Advanced Nursing, 22(1), 278-308. https://doi. org/10.1111/j.1365-2648.1995.tb02653.x

Beatty, J.E. (2012). Career barriers experienced by people with chronic illness: A U.S study. Employee Responsibilities and Rights Journal, 24, 91-110. https://doi. org/10.1007/s10672-011-9177-z

Belzil, C., \& Bognanno, M. (2010). The promotion dynamics of American executives. Research in Labor Economics, 30, 189-231. https://doi.org/10.1108/S0147-9121 (2010)0000030009

Boyce, C., \& Neale, P. (2006). Conducting in-depth interviews: A guide for designing and conducting in-depth interviews for evaluation input. Retrieved June, 2012, from http://www.pathfind.org/site/DocServer/m_e_tool_series_indepth_interviews. pdf?doclD=6301

Buciuniene, I., \& Kazlauskaite, R. (2010). Integrating people with disability into the workforce: The case of a retail chain. Equality, Diversity and Inclusion: An International Journal, 29(5), 534-538. https://doi.org/10.1108/02610151011 052816
Burns, N., \& Grove, S.K. (1997). The practice of nursing research: Conduct, critique and utilization (3rd edn.). Philadelphia, PA: WB Saunders.

Chan, J.F. (2010). Training fundamentals. San Francisco, CA: Pfeiffer.

Christianson, M. (2012). People with disabilities inside (and outside) the South African workplace: The current status of the constitutional and statutory promises. Acto Juridica: Reinventing Labour Law, 286-305.

Cole, E.C., \& Van der Walt, A. (2014). The effect of labour legislation in the promotion and integration of persons with disabilities in the labour market. Obiter, 35(3), 506-538.

Commission for Employment Equity Annual Report (2012, 2013, 2014). Retrieved May 13, 2016, from http://www.labour.gov.za/DOL/documents/annual-reports/ Commission $\% 20$ for $\% 20$ Employment $\% 20$ Equity\%20Report/2014-2015/ Commission $\% 20$ for $\% 20$ Employment $\% 20$ Equity $\% 20$
commission-for-employment-equity-report-2014-2015

Creswell, J.W. (2007). Qualitative inquiry and research design: Choosing approaches (2nd ed.). Thousand Oaks, CA: Sage.

Crowther, N. (1999). Overcoming disability discrimination: Disabled people, housing and social exclusion. Housing, Care and Support, 16-20. https://doi.org/10.1108/ 14608790199900034

Daya, P. (2014). Diversity and inclusion in an emerging market context. Equality, Diversity and Inclusion: An International Journal, 33(3), 293-308. https://doi. org/10.1108/EDI-10-2012-0087

Department of International Relations and Cooperation. (2013). International Labour Organization (ILO). Retrieved June 11, 2013, from http://www.dfa.gov.za/foreign/ Multilateral/inter/ilo.htm

De Vos, A.S., Strydom, H., Fouche, C.B., \& Delport, C.S.L. (2011). Research at grass roots: For the social sciences and human service professions. Pretoria, South Africa: Van Schaik Publishers.

Gida, P., \& Ortlepp, K. (2007). Employment of people with disabilities: Implications for HR management practices. Acta Commercii, 7, 135-150.

Gowan, N.J. (2010). HR manager's guide to managing disability in the workplace (1st ed.). Toronto, Canada: Thomson Reuters.

Guba, E.G., \& Lincoln, Y.S. (1994). Competing paradigms in qualitative research. In N.K. Denzin \& Y.S. Lincoln (Eds.), Handbook of qualitative research (pp. 105-117). Thousand Oaks, CA: Sage.

Guimaraes, B.B., Martins, L.B., \& Barkokebas Junior, B. (2012). Issues concerning scientific production of including people with disabilities at work. Work, 41, 4722-4728.

Hashim, J., \& Wok, S. (2014). Predictors to employees with disabilities' organisational behaviour and involvement in employment. Equality, Diversity and Inclusion: An International Journal, 33(2), 193-209. https://doi.org/10.1108/EDI-03-2012-0018

Hasse, J. (Ed.). (2011). Perfectly able: How to attract and hire talented people with disabilities. New York: AMACOM.

Hernandez, B., McDonald, K., Divilbiss, M., Horin, E., Velcoff, J., \& Donoso, O. (2008). Reflections from employers on the disabled workforce: Focus groups with healthcare, hospitality and retail administrators. Employee Responsibilities \& Rights Journal, 20(3), 157-164. https://doi.org/10.1007/s10672-008-9063-5

Hesse-Biber, S.N., \& Leavy, P. (2004). Approaches to qualitative research: A reader on theory and practice. Oxford, UK: Oxford University Press.

Hsieh, H., \& Shannon, S.E. (2005). Three approaches to qualitative content analysis. Qualitative Health Research, 15, 1277-1288. https://doi.org/10.1177/104973230 5276687

Hussein, S., Manthorpe, J., \& Ismail, M. (2014). Ethnicity at work: The case of British minority workers in the long-term care sector. Equality, Diversity and Inclusion: An International Journal, 33(2), 177-192. https://doi.org/10.1108/EDI-02-2013-0009

International Labour Organisation. (2011). International Labour Organization (ILO). Retrieved May 13, 2016, from http://www.ilo.org/wcmsp5/groups/public/@ dgreports/@dcomm/@publ/documents/publication/wcms_150440.pdf

Jakovljevic, M., \& Buckley, S. (2011). Assistive technologies in a workplace environment: Barriers for the employment of persons with disabilities. Dcidj, 22(2), 55-78. https://doi.org/10.5463/dcid.v22i2.32

Jones, M.K. (2008). Disability and the labour market: A review of the empirical evidence. Journal of Economic Studies, 35(5), 405-424. https://doi.org/10.1108/ 01443580810903554

King, E.C., \& Horrocks, C. (2010). Interviews in qualitative research. London, UK: Sage.

LaPierre, T.A., \& Zimmerman, M.K. (2012). Career advancement and gender equity in healthcare management. Gender in Management: An International Journal, 27(2), 100-118. https://doi.org/10.1108/17542411211214158

Leedy, P.D., \& Ormrod, J.E. (2005). Practical research: Planning and design (8th ed.). Upper Saddle River, NJ: Pearson Prentice Hall.

Leedy, P.D., \& Ormrod, J.E. (2010). Practical research: Planning and design (9th ed.). Upper Saddle River, NJ: Pearson Prentice Hall.

Lengnick-Hall, M.L., \& Gaunt, P. (2007). Why employers don't hire people with disabilities. In M.L. Lengnick-Hall (Ed.), Hidden talent: How leading companies hire, retain, and benefit from people with disabilities (pp. 2-6). Westport, CT: Praeger.

Li, Y., \& Goldschmidt, J. (Eds.). (2009). Taking employment discrimination seriously: Chinese and European perspectives. Boston, MA: Maritinus Nijhoff Publishers.

Lindstrom, L., Doren, B., \& Miesch, J. (2011). Waging a living: Career development and long-term employment outcomes for young adults with disabilities. Exceptional Children, 77(4), 423-434.

Lourens, A., \& Phabo, L. (2015). Diversity management: the management of disabled persons within the SANDF. Journal of Public Administration, 50(1), 634-643. 
Management Today. (2011). Disabled South Africans have few freedoms to celebrate. Pretoria, South Africa: Author.

Marumoagae, M.C. (2012). Disability discrimination and the right of disabled persons to access the labour market. Potchefstroom Electronic Law Journal, 15(1), 345-365. https://doi.org/10.4314/pelj.v15i1.10

Maxwell, J.A. (2005). Qualitative research design: An interactive approach (2nd edn.). Thousand Oaks, CA: Sage.

Neuman, W.L. (2003). Social research methods: Qualitative and quantitative approaches. Boston, MA, USA: Allyn \& Bacon.

Ofuani, A.I. (2011). The right to economic empowerment of persons with disabilities in Nigeria: How enabled? African Human Rights Law Journal, 11(2), 639-658.

Oosthuizen, R.M., \& Naidoo, V. (2010). Attitudes towards and experience of employment equity. SA Journal of Industrial Psychology, 36(1), 1-9. https://doi. org/10.4102/sajip.v36i1.836

Parlalis, S.K. (2013). Legal framework against disability discrimination at work in Cyprus. Equality, Diversity and Inclusion: An International Journal, 32(4), 426-437. https://doi.org/10.1108/EDI-07-2012-0055

Rahmania, M., Akhter, R., Chowdhury, S., Islam, S., \& Haque, M.R. (2013). HRM practices and its impact on employee satisfaction: A case of pharmaceutica companies in Bangladesh. International Journal of Research in Business and Social Science, 2(3), 2147-4478.

Richards, L. (2009). Handling qualitative data: A practical guide (2nd ed.). London: Sage.

Searle, R.H. (2003). Selection \& recruitment: A critical text. London, United Kingdom: The Open University.

Sing, D., \& Govender, V. (2007). Establishing enabling structures and measures for people with disabilities in the South African Public Service. Journal of Public Administration, 42(8), 786-797.

Smith, M. (2012). Application of the international classification of functioning, disability and health with specific focus on disabling hearing impairment in legislation and policy in South Africa. Journal for Juridical Science, 37(2), 96-116.

Sommo, A., \& Chaskes, J. (2013). Intersectionality and the disability: Some conceptual and methodological challenges. Research in Social Science and Disability, 7, 47-9. https://doi.org/10.1108/S1479-3547(2013)0000007005
South African Human Rights Commission Annual Report. (2012). Retrieved May 13, 2016, from http://www.sahrc.org.za/home/21/files/Annual\%20Report\%20201213.pdf\%200ctober.pdf

Statistics South Africa. (2014). Census 2011: Profile of persons with disabilities in South Africa. Retrieved September 30, 2014, from http://beta2.statssa.gov.za/ publications/Report-03-01-59/Report-03-01-592011.pdf

Terre Blanche, M., Durrheim, K., \& Painter, D. (2006). Research in practice: Applied methods for the social sciences. Cape Town, South Africa: University of Cape Town Press.

Tesch, R. (1990). Qualitative research: Analysis, types and software tools. New York The Falmer Press.

Thomas, A.B. (2004). Research skills for management studies. London, UK: Routledge.

Tuwei, J.G., Matelong, K.N., Boit, S.R., \& Tallam, K.Z. (2013). Promotion opportunity on employee career change decision: The case of a selected learning institution in Kenya. International Journal of Business and Management, 8(18), 53-62.

Van Niekerk, Z., \& van der Merwe, J. (2013). Participation opportunities for persons with disabilities in training interventions in the dti and CIPRO. SA Journal of Human Resource Management, 11(1), 1-12. https://doi.org/10.4102/sajhrm. v11i1.466

Vickers, M.H. (2009). Why people with disabilities might really be leaving work: An exemplar case with lessons. In R.C. Preziosi (Ed.), The 2009 Pfeiffer Annual: Management Development (pp. 139-154). San Francisco, CA: Pfeiffer.

Watermeyer, B., Swartz, L., Lorenzo, M., \& Priestley, M. (Eds.). (2006). Disability and social change: A South African agenda. Cape Town: HSRC Press.

Wehman, P.H. (2011). Employment for persons with disabilities: Where are we now and where do we need to go? Journal of Vocational Rehabilitation, 35, 145-151.

World Health Organization. (2011). World report on disability. Retrieved April 17, 2014 from http://whqlibdoc.who.int/publications/2011/9789240685215_eng.pdf

Ximba, T. (2016). Career advancement challenges facing people with disability in South Africa. Unpublished Master's Dissertation. Pretoria: University of South Africa.

Zondi, D. (2009). The effectiveness of the Employment Equity Act (Act 55 of 1998) in the public service with reference to the Department of Agriculture 2000-2006: South African perspective. Master's thesis, University of Pretoria, Pretoria. 